\title{
Calcitonin Participant in the Development of Insulin Resistance
}

\section{Svetlana Stepanovna Moisa}

Federal State-Financed Establishment of Science, State Scientific Center of Russian Federation, Institute of Biomedical Problems of the Russian Academy of Sciences, Moscow, Russia

Correspondence to: Svetlana Stepanovna Moisa, butalana07@list.ru

Keywords: Calcitonin, Insulin, Insulin Resistance, Diabetogenic Effect, Risk Factor, Calcium Channel Blockers Received: May 31, 2017 Accepted: July 12, $2017 \quad$ Published: July 17, 2017

Copyright $\odot 2017$ by author and Scientific Research Publishing Inc.

This work is licensed under the Creative Commons Attribution International License (CC BY 4.0).

http://creativecommons.org/licenses/by/4.0/

(c) (i) Open Access

\section{ABSTRACT}

The review contains contemporary literature data about calcitonin role in the development of insulin resistance and its potential role in the pathogenesis of carbohydrate metabolism disturbances. Analogues disturbances revealed under diabetes mellitus and under calcitonin treatment are considered. Literature data about hormone diabetogenicity are discussed. The analysis of experimental and literature data testifies that calcitonin under unfavorable conditions (age, obesity, stress) against the background of the decreasing of functional activity of insular apparatus can lead to the development of metabolic syndrome and diabetes mellitus. It is shown that calcium channel blockers inhibit calcitonin effect leads to glucose intolerance and decreases tissue insulin sensitivity. In this connection a question about direct influence on calcium mechanisms of endocrine system as possible method of drug therapy is discussed.

\section{INTRODUCTION}

Fifty five years, having past after the discovery of thyroid gland hormone-calcitonin (CT), have brought a lot of contradictory facts and interpretations. The main action of CT is the decreasing of calcium serum concentration, mainly due to the calcium sediment in bones and reduction of bone tissue resorption. However, biological significance of CT for mammals, including man, remains to an end unknown. On the one hand, there is no doubt about hypocalcemic, hyperglycemic and analgetic action of $\mathrm{CT}$, on the other hand, CT role in glucose metabolism regulation isn't completely clear. Besides, the disturbances, which arise in organism under the excess or deficiency of mature CT, are not detected till now. Lately some new facts of CT effect on carbohydrate metabolism, enlarging the notions about its physiological role, which significance in organism, apparently, much more than it is suggested yet recently [1]. 


\section{CALCITONIN AND INSULIN RESISTANCE}

Insulin resistance (IR) is the reducing of biological effects (glucose assimilation) in tissues and organs to the answer for insulin action on the specific cell receptors. At present there are more than 40 diseases, under which IR develops, are known. Some reasons of IR development can be stresses, Mg deficiency, hypodynamia, alcohol excess and the increasing of contra-insular hormones level. The enhancing level of contra-insular hormones pays the especial attention. As far as we think, that CT for its effect on glucose homeostasis can regard to contra-insular hormones [2,3], so, hypercalcitoninemia, induced by stress influence [4] or in case of CT treatment, under the unfavorable conditions can lead to the development of IR. We'll consider CT participant in the development of IR in brief.

Three levels of IR. IR can develop on pre-receptor level: disorder of pancreas $\beta$-cell function; cell level: decreasing of tissue insulin sensitivity; liver level: increasing of glucose production. As it is known, $B$-cell function, secreting insulin, especially clear reveals under the glucose-tolerant test. The sensitivity of $B$-cells to glucose is most important quantitative parameter of their functional capacity [5]. CT inhibits insulin secretion against the background of glucose load per os and provokes glucose intolerance [3], i.e. promotes to the development of IR on the pre-receptor level. The mechanism of CT effects on insulin secretion remains unclear. It can be hypothesized that CT-induced hypocalcemia reduces intracellular $\mathrm{Ca}^{2+}$ concentration in $\beta$-cell cytosol, decelerates the release of secretory granules localized in microfilament network near the cell membrane [6], thus delaying insulin secretion during GTT. It can be hypothesized that this specific feature of insulin secretion under the effect of CT determines the previously described impairment of alimentary hyperglycemia.

A lot of drugs get worse insulin secretion, and some of them induce a toxic damage of pancreas $\beta$-cells. So, it is established, that thyroxin in high doses induces apoptosis of pancreas $\beta$-cells in rats and, that thyroxin effect reverse. In this connection, it is thought, that hyperthyroidism can accompany by the strengthening of $\beta$-cells apoptosis, leading to the decreasing of basal insulin level and its secretion under glucose effect [7]. It is interesting to note, that CT treatment of rats during 20 days induce the increasing of blood thyroid hormones concentration [8]. So, one may suppose still more mechanism, by which CT can get worse functional state of pancreas $\beta$-cells. Apparently, it lies in that, CT by virtue of increasing of thyroid hormones concentration, which is capable to induce apoptosis of $\beta$-cells, can indirect reduce $\beta$-cells activity.

Glucose level change under the per-oral test to glucose tolerance is the result of peripheral glucose utilization and its production in liver [9]. Peripheral glucose utilization testifies about tissue insulin sensitivity. Insulin induces translocation of glucose transporters GLUT-4 from intracellular depots to the plasma membrane, which leads to increased glucose consumption by the muscle and adipose tissues. The disturbance of insulin capacity to induce translocation of own glucose transporters GLUT-4 from intracellular depot to the plasma membrane leads to IR and the development of diabetes mellitus 2 type [10]. CT reduces the sensitivity of the muscle and adipose tissues to insulin in experiments in vivo and in vitro [11], i.e. promotes the development of IR on the cell level. The following mechanism of this non-specific action of CT can be hypothesized. CT acting on non-specific receptors through $\mathrm{Ca}^{2+}$-dependent processes enhances $\mathrm{Ca}^{2+}$ entry through L-type $\mathrm{Ca}^{2+}$ channels, thus increasing intracellular $\mathrm{Ca}^{2+}$ concentration, and triggers the $\mathrm{Ca}^{2+}$ release from depots that inhibits insulin-stimulated mobilization of GLUT-4 from intracellular depots to the plasma membranes.

CT increases glucose level in blood (hyperglycemic effect). The mechanism of hyperglycemic effects of CT preparations is poorly studied; previous findings suggest that they are related to inhibitory effects of CT on insulin secretion and glucose utilization by peripheral tissues and activation of glycogenolysis processes [12]. As a result glucose production stimulates in liver. CT reveals hyperglycemic and glycogenolytic effect due to the intensifying of the processes of glycogenolysis and gluconeogenesis, i.e. CT promotes the development of IR on the liver level.

Thus, CT participates in the development of IR on the pre-receptor, cell and liver levels.

Insulin antagonists in the development of IR. Besides, one of the reasons of the pre-receptor type IR is the presence in circulation insulin antagonists, which can be hormonal and non-hormonal nature. To 
hormonal antagonist attribute to glucagon, corticosteroids, catecholamines, STH and other factors, they are contra-insular ones regarding to mechanism action on some metabolic processes. According to insulin action their antagonism reveals and on the level of insulin-receptor system. In this connection one should note, that $\mathrm{CT}$ increases the content of insulin inhibitors, leading to the decreasing of its biological activity. So, STH, catecholamines and cortisol levels in blood increase under the effect of CT $[13,14]$, i.e. CT also indirect can promote to the development of IR. These data testify about the significance of stress and contra-insular hormones in the development of IR.

To non-hormonal insulin antagonists attribute to antibodies to insulin and antibodies to insulin receptors, ketone bodies, free fatty acids, sin albumin. It is considered that free fatty acids play an important role on the early stages of IR development [15], and enhanced triglycerides level promotes to the development of IR [16]. A clear positive correlation between the increasing of free fatty acids and triglycerides concentration in blood and the degree of resistance to insulin in muscle and adipose tissue is revealed [15]. Free fatty acids are considered as a new marker of IR [17]. The investigations of the last years were shown that fatty acids inhibit insulin-stimulated glucose transport in muscle cells [18]. It is also established, that chronic increasing of free fatty acids in serum leads to IR development [15] and that fatty acids induce IR of man skeletal muscles due to the defects of insulin-dependent glucose transportation [18]. Enhanced free fatty acids level reveals the direct metotoxical effect on the secretory function of pancreas $\beta$-cells and decreases insulin-dependent glucose utilization by muscle cells, resulting peripheral IR develops. CT increases the level of free fatty acids [19] and this way also promotes to IR development.

CT decreases C-peptide level in blood [20], it testifies about the increasing of proinsulin concentration-less active form of insulin.

$\mathrm{Ca}^{2+}$ plays the definite role not only in secretion, but and in realization of insulin action. According to the obtained data in vitro, $\mathrm{Ca}^{2+}$ increases insulin receptor activity in rat's adipose, as a result the dissociation hormone with cell membrane reduces and, so, the effectiveness of hormone action enhances [21]. Indirect one may suppose that $\mathrm{CT}$, decreasing $\mathrm{Ca}^{2+}$ level, can reduce insulin receptor activity. This fact is worth of attention as far as it is thought that IR develops due to the decreasing of amount of receptors to insulin and defects of insulin-dependent glucose transportation [22].

$I R$ in the development of diseases. In accordance with the concept of G.M. Reaven [23], IR is a basic component of the metabolic syndrome [24], along with obesity, arterial hypertension, dyslipidemia (elevated triglycerides and low high-density lipoprotein cholesterol), and impared glucose metabolism (high fasting glucose, impaired glucose tolerance). The progression of the metabolic syndrome leads to the development of prediabetes, diabetes, cardiovascular disease, nonalcoholic fatty liver disease, gout, syndrome of hyperandrogenism (polycystic ovaries) and cancer. It is known also, that firm IR reveals by glucose intolerance and, finally, leads to the formation of diabetes mellitus 2 type. Some patients with low progressive autoimmune diabetes have the symptoms of metabolic syndrome and peripheral IR at that [25]. In this connection it is interesting to note, that in patients with diabetes mellitus 2 type the risk of the development of micro-vascular complications determines not only chronic hyperglycemia, but and a number of metabolic syndrome components [26].

It is also known, that diabetes mellitus accompanies by the osteoporosis development. At that time it is established, that glucocorticoids treatment during 6 months can lead to the development of osteoporosis-a most often form of osteoporosis, induced by the drugs [27]. It is thought, that CT deficiency can serve as a factor in osteoporosis development [28]. One can suppose that in the pathogenesis of osteoporosis under diabetes mellitus participate both calcium-regulating hormones and glucocorticoids.

Conclusion. Thus, these data allow conclude, that CT participant in IR development reveals on the different levels: pre-receptor-effecting on the functional state of $\beta$-cells, direct-inhibits insulin secretion, indirect-increases thyroid hormone level, inducing apoptosis of $\beta$-cells, stimulates hormonal secretion (STH, cortisol, catecholamines) and non-hormonal (free fatty acids) antagonists of insulin, reducing the activity of insulin receptors, resulting is the reduction of $\beta$-cells action; cell level-decreasing insulin sensitivity of muscle and adipose tissue and preventing glucose assimilation via disturbance of glucose transporters GLUT-4 translocation on cell membrane; liver level-increasing glucose production due to the 
intensification of glycogenolysis and gluconeogenesis processes.

The data analysis about antagonistic CT action concerning to insulin allows suppose about diabetogenity of hormone.

\section{DIABETOGENIC EFFECT OF CALCITONIN}

It is known some cases of disorders, connecting with the excessive secretion or exogenic treatment of hormones-antagonists of insulin, leading to the development of diabetes mellitus. So, steroid diabetes can arise under the hyper-secretion of glucocorticoids or their long-lasting treatment as drug and doesn't arise in case of hyper-secretion of other steroid hormones, such as mineral-corticoids or sex hormones, which occurs non-significant effect on carbohydrate metabolism. As to CT, there is no single opinion about CT diabetogenic effect in literature data, but fact data are rather contradictory [29, 30]. The suggestion about CT diabetogenicity was said as far back as in 1983 [31]. However, clinical observations for the patients with Paget's disease, receiving a long-time CT treatment, are not identical. Some authors [30] describe the hyperglycemic effect of synthetic salmon CT and the existence of a strong reverse correlation between plasma calcium level and glucose level, and others [29] didn't reveal the symptoms of diabetes mellitus in patients with Paget's disease even after 8 years of CT treatment. These data allow suppose that diabetic effect of CT reveals not always, but, apparently, under the changing of the initial state of pancreas $\beta$-cells, especially under their intensive activity.

\section{CALCITONIN EXCESS CAN PROMOTE TO THE DEVELOPMENT OF METABOLIC SYNDROME AND DIABETES MELLITUS UNDER UNFAVORABLE CONDITIONS}

It was interesting to research CT effect on glucose homeostasis under the alteration of pancreas functional state, for example, under obesity and in elderly age, too.

It is admitted to suppose, that CT, long-lasting high concentration in blood, and especially under unfavorable conditions (obesity, age, aggravating heredity et al.) can act on insulin receptors indirect due to the metabolic processes and induce the development of the relative insulin deficiency caused by the decreasing of its biological activity. In view of that, the results of the examinations of children-teenagers 10 14 years old with the 1-st degree obesity and negative calcium balance, receiving one-time injection of CT [32], are worse of attention. The establishment of glucose intolerance under CT effect in glucose tolerance test in children one may consider as an example of negative CT influence on glucose homeostasis under unfavorable conditions, in this case, obesity. Obesity is not only risk factor of the development of mellitus type II diabetes, but and its complications [33]. In children with obesity, metabolic disorders were identified, such as IR and dyslipidemia of an atherogenic nature, which increase with obesity [34]; they have a violated metabolism of glucose, lipids, uric acid [35], elevated levels of insulin, C-peptide [36], and free fatty acids in the blood plasma [37]. According to Kravets E.B. opinion [38], elevated basal insulin level and $\mathrm{C}$-peptide are connected with the strengthening pancreas insular apparatus, what testify about the weakening of efficiency of endogenous insulin effect on peripheral.

In our previous investigations [39] more marked impaired glucose tolerance were revealed in mature and old rats during glucose tolerant test against the background of CT. As it is known, the state of the insular apparatus of the pancreas suffers significant changes with age. With the aging of an organism, a relative insulin deficiency develops, caused, despite of high blood insulin content, by decreasing its biological activity. Besides the reduction of insulin-stimulating glucose transport in the elderly persons with normal reaction on oral glucose tolerant test was established [40]. On this background one-time injection of CT in mature and old animals induced more marked glucose intolerance, i.e. a negative influence of CT on glucose homeostasis revealed and in animals in mature and old age, when there are the changing of initial state of pancreas $\beta$-cells, i.e. under its intense activity.

These data indicate that one-time CT injection led to the decreasing of functional state of $\beta$-cells under the obesity and in elderly age. In this, it is important to note, that the disturbance of $\beta$-cells function, leading to IR, was revealed in mice with the model of mellitus type II diabetes [41]. As it is known, desen- 
tization of insulin secretion is an important stage of the manifestation of mellitus type II diabetes [42]. So, under unfavorable conditions, namely, under obesity and also in elderly age, CT can promote to the development of the disturbances of carbohydrate metabolism. It should be noted, that in base of the disturbances of carbohydrate metabolism, such as, metabolic syndrome, diabetes mellitus, and also obesity, there are common metabolic disorders-glucose intolerance, IR and hyperinsulinemia.

Besides, the leading role in the development of metabolic syndrome and diabetes mellitus is given to chronic stress. In this, one should mean, that enhanced CT secretion meets under stress situations, as a result, a hypercalcitoninemia arises [4]. In these situations endogenous CT happen the same effect on the regulation of carbohydrate metabolism as exogenous injections of hormone preparations.

Previously we considered the question about the reduction of tissue insulin sensitivity under CT effect [11]. According to Baranov V.G. [43], decreased tissue sensitivity to insulin is an important link in the pathogenesis of diabetes, and factors, causing a decline in insulin sensitivity, can be considered as risk factors for the incidence of diabetes. So, in our opinion, one can suppose, that concerning to glucose homeostasis CT under definite conditions (age, aggravating heredity, obesity, stress,) can promote to the development of metabolic syndrome and diabetes mellitus, i.e. CT can consider as a "risk factor" of diabetes mellitus. Besides, as Lasyi V.P. [44] thinks, pathological shifts in carbohydrate metabolism, in one's turn, are caused by the disturbances of insulin secretion. Our investigations was shown the inhibition of insulin secretion under $C T$ [3], as it is known, insulin deficiency leads to the development of diabetes mellitus. So long as, insulin effect can be modify by CT action, so also one may think about CT potential role in the pathogenesis of the disturbances of carbohydrate metabolism.

Above-stated allow conclude, that diabetogenic CT effect depends on dose treatment, and also initial state of $\beta$-cells. It isn't ruled out, that clinic cases of diabetes mellitus arise only under the combination CT effect and latent defective of $\beta$-cells (latent diabetes). In this, it is interesting to note, that in patients with primary manifested diabetes the content of immune CT and parathyrine in blood increase, but in compensation phase of disease under insulin therapy the tendency to normal level of these hormones was observed [45].

We consider, that CT, inhibiting insulin secretion, inducing IR and glucose intolerance, and as a matter of fact, being, in our opinion, contra-insular hormone, can promote to the development of metabolic syndrome and diabetes mellitus, as it happens, for example, in case of hypersecretion of glucocorticoids or its long-lasting therapy.

Preparations of CT effectively use for the treatment of hypercalcemia states (hyperparathyroidism, intoxication of vitamin D), osteoporosis and osteoarthritis, sport trauma, for the acceleration of healing of bone fractures, anaesthetization under metastasis in bone tissue, phantom pain, migraine, in dentistry, psychiatry, under the treatment of back pains, disease of stomach and duodenal ulcer in present time [1]. Contra-indications for CT treatment are hypocalcaemia, pregnancy, lactation. One should have in mind that circumstance that under chronic increasing of CT in blood (both in the result of treatment and in case of CT-produced tumors) target-organs adapted to CT and stop to answer by the disorder of its function for the increasing of serum CT level. But this adaptation is reverse: after the break in CT treatment the initial reaction of target-organ on this hormone restores [31].

These arguments of CT participant under unfavorable conditions in IR development have extremely important significance for the elucidation of origin mechanisms of metabolic syndrome, connected both with hyperinsulinemia and glucose intolerance, and obesity.

The discussed data about CT participant in the regulation of glucose metabolism indicate about contra-insular character its action, enlarge the conception about its physiological role and allow recommend to take into account its effect on glucose metabolism under its treatment in clinic practice.

\section{METABOLIC DISORDERS UNDER DIABETES MELLITUS AND UNDER CALCITONIN TREATMENT}

Metabolic disorders, induced by CT, are observed and under diabetes mellitus. This fact is worthy of 
special attention. So, a significant increasing of LDG activity was found under diabetes [46] and in pre-diabetic state and tendency to diabetes [47], and also in our investigations after CT treatment to rats [12].

The enhancement of free fatty acids level was noted against the background of CT injection [19] and in patients with insulin-dependent diabetes on an empty stomach and after receiving of food [48].

It should be noted and the appearance of anti-bodies to CT in blood in rats under alloxan diabetes, which marks only under high blood glucose level. A correlation between blood glucose level and anti-bodies to CT was found [49]. The authors think that the appearance of auto-anti-bodies to CT serves as a pathogenetic factor of the development of hyperglycemia under alloxan diabetes.

\section{CALCIUM CHANNEL BLOCKERS IMPROVE INSULIN RESISTANCE}

In present time a many-promised tendency in the investigations of the mechanisms of the functioning of excitable cells is the combination of physiological and bio-physical methods with using of pharmacological drugs.

According to Kosovsky M.I.'s opinion [50], there is a system of insulin sensitivity regulation in organism, which reacting both on the different physiological and pathological changing, and on pharmacological effects. A reverse decreasing of the secrete answer of $\beta$-cells arises in the result of long-lasting effect of numbers of stimulus: glucose (the main physiological stimulator), free fatty acids, all pharmacological stimulators, induced depolarization and enters $\mathrm{Ca}^{2+}$ into the cells. Many pharmacological drugs, which are capable to interrelate with the structures of ions channels and installed in surface membrane, can influence on the character of their single or multiple rhythmical work, alter the rest potential of cells, synaptic and rhythm-conducting potentials, the parameters of action potential, neuronal and muscle membranes, and, consequently, to regulate their activity in organism.

The interest to the mechanisms of CT effect on glucose homeostasis is explained also by the search of some means of management by this most important bio-regulator. In this point of view the data of studying the interaction of CT and calcium channel blockers (CCB) in plan of the analysis of possible mechanisms of hormone action attract attention. In experiments in vivo and in vitro, it was shown that isoptin blocked the inhibiting effect of CT and Bay-K 8644 in vitro, on the contrary, intensified the inhibiting effect of CT on insulin-stimulated glucose consumption by muscle and adipose tissue [11]. Isoptin, the blocker of slow voltage-dependent L-type $\mathrm{Ca}^{2+}$ channels, reduces $\mathrm{Ca}^{2+}$ transport and Bay-K 8644, L-type $\mathrm{Ca}^{2+}$ channels agonist, increases $\mathrm{Ca}^{2+}$ transport across the sarcolemma. Modulation of the inhibitory effect of CT on insulin-stimulated glucose consumption in the muscle and adipose tissue by isoptin and Bay-K8644 indicates that $\mathrm{Ca}^{2+}$ ions and L-type $\mathrm{Ca}^{2+}$ channels participate in the process. After binding to the receptor, insulin induces various cell responses, including $\mathrm{Ca}^{2+}$ influx into the cytoplasm and amino acid and sugar consumption. It is known, that $\mathrm{Ca}^{2+}$ channels were revealed in skeletal muscles, liver, pancreas, neuro-endocrine tissue, brain, and smooth muscles of vertebrates and other tissues [51] and in human adipocytes [52]. Intracellular $\mathrm{Ca}^{2+}$ plays a key role in metabolic disorders associated with obesity and insulin resistance [53]. According to some authors, endogenous $\mathrm{Ca}^{2+}$ can be involved in the development of diabetes mellitus via decreased insulin sensitivity [54]. Moreover, disorders in Ca-P metabolism were revealed in patients with diabetes mellitus type I [55], and disorders in cell $\mathrm{Ca}^{2+}$ homeostasis were revealed in skeletal, cardiac muscles, erythrocytes, liver, adipocytes, and pancreatic $\beta$-cells of patients with diabetes mellitus type $2[56,57]$; negative $\mathrm{Ca}^{2+}$ balance was observed in 6-16-year-old children with diabetes mellitus type 1 $[55,58,59]$. It is established that the alterations of $\left[\mathrm{Ca}^{+}\right]$i concentration in early stages of diabetes mellitus can play a causal role in the reduction of hemodynamic, induced by the slowing heard work [60]. Ward D. et al. [61] established the increasing of calcium excretion with urine in rats with streptozotocin diabetes mellitus.

In our previous studies we have shown that isoptin, reducing the concentration of intracellular $\mathrm{Ca}^{2+}$, blocks the inhibitory effect of CT on insulin-stimulated glucose uptake by muscle and adipose tissue, probably, due to higher levels of glucose transporters GLUT-4, resulting in increased glucose uptake by 
peripheral tissues, thereby preventing the development of insulin resistance [11]. These data are found the verification in literature. Thus, nifedipin (calcium channel blocker) therapy not only promotes to the decreasing of arterial pressure, but and improves IR in the elderly patients with hypertension [62]. This fact is worth of attention and in connection with that the reduction of GLUT-4 content in myocardium sarcoplasm was discovered under diabetes mellitus [63].

There is some information about metabolic neutrality CCB [64-67]. It is established, that CCB-isoptin and nifedipin, reducing total calcium level in blood serum, didn't occur reliable effect on glucose level and at the same time inhibited hyperglycemic effect of CT under their combinative treatment, abolished glucose intolerance, induced by CT injection, during glucose tolerant test [68] and prevented the development of IR [11]. It is supposed that CCB therapy can be correction method of hyperglycemia and tissue IR [69].

The ability of CCB completely to abolish the hyperglycemic effect of CT testifies about that these types of $\mathrm{Ca}^{2+}$ channels (slow voltage-dependent L-type and chemo-sensitive) take part in the realization of this hormone action. In this, it is logically to assume that, the blocking of $\mathrm{Ca}^{2+}$ channels of membrane of non-specific organs by $\mathrm{CCB}$, decreasing $\mathrm{Ca}^{2+}$ transport through sarcoplasm cell membrane, leads to the inactivation of the mechanisms, which are in base of hyperglycemic CT effect. Apparently, CT, revealing its effect on non-specific receptors via calcium-dependent processes, enhances $\mathrm{Ca}^{2+}$ entry via L-type $\mathrm{Ca}^{2+}-$ channels thus increasing the intracellular $\mathrm{Ca}^{2+}$ concentration. As it is known, excessive $\mathrm{Ca}^{2+}$ entry or its impaired removal from the cell, are accompanied by impairment of intrinsic cell functions. Thus, intracellular $\mathrm{Ca}^{2+}$ plays a key role in the development of a range of pathologies (hypertension, cardiac arrhythmia, diabetes mellitus, encephalopathy, dementia, and others), and also can accelerate aging process. So, the metabolic effect of CCB is concluded in their effect on glucose utilization on cell level due to the reducing of intracellular $\mathrm{Ca}^{2+}$ content. Probably, this mechanism can underlie the inhibitory effect of CCB on the hyperglycemic effect of CT.

Thus, these data, that CCB provoke the improvement of IR and glucose tolerance, induced by CT injection, testify about the drawing of $\mathrm{Ca}^{2+}$-mechanisms into these processes and about that $\mathrm{CCB}$ can further to the correction of hyperglycemia and tissue IR. It is known also, that CCB effect and on other components of metabolic syndrome, revealing athero-protective [70], hypotension [71], lipolytic [72], antianginal, neuro-protective action.

The understanding of cell mechanisms of IR allows developing new method of aim-tendency therapy of metabolic syndrome and diabetes mellitus II type. Calcium channels (both potassium and sodium) are regulated and modulated by hormones, neurotransmitters and proteins. In recent time there are some conceptions about cyto-, membrane- and channelo-pathies begin to develop [73]. In the connection that it is established the important role of $\mathrm{Ca}^{2+}$-channels L-type in the regulation of glucose-stimulated insulin secretion by $\beta$-cells $[74,75]$ and, that during the development of diabetes mellitus in rats Zuker occur the decreasing of expression of mRNA C-and $\mathrm{D}$-isoforms $\alpha_{1}$-subunits potential-dependent $\mathrm{Ca}^{2+}$-channels $\mathrm{L}$-type in $\beta$-cells their pancreas, what correlates with the lowering of $\mathrm{Ca}^{2+}$-current $\mathrm{L}$-type $\left(\mathrm{I}_{\mathrm{Ca}}\right)$, it is logically to suppose about the role of $\mathrm{Ca}^{2+}$-channels L-type in insulin secrete answer on glucose, in its disturbances under diabetes mellitus and methods of its correction. Ion channels are considered as disease targets. It is the subject of discussions last year $[69,75]$. It was shown, that voltage-controllable ion channels are effective target of cyto-pharmacological regulation of the functional state [73]. The idea of direct influence on $\mathrm{Ca}^{2+}$-mechanisms of endocrine system as possible method of drug therapy forms on the base of these data last years.

\section{REFERENCES}

1. Moisa, S.S. and Nozdrachev, A.D. (2011) Mechanisms of Calcium and Carbohydrate Metabolism Regulation. LAP LAMBERT Academic Publishing GmbH \&Co. KG, Saarbrucken.

2. Butakova (Moisa), S.S. and Nozdrachev, A.D. (2010) Calcitonin-Contra-Insulin Hormone. Advances in Gerontology, 23, 364-370. 
3. Moisa, S.S. (2013) Contra-Insulin Effect of Calcitonin on Glucose Metabolism. Bulletin of Experimental Biology and Medicine, 156, 183-185. https://doi.org/10.1007/s10517-013-2314-y

4. Drzhevetskaya, I.A. and Mishina, N.F. (1978) Thyrocalcitonin Participant in Stress Development. The Journal of Physiology, 64, 864-868.

5. Ferrannini, E. and Mari, A. (2004) Beta Cell Function and Its Relation to Insulin Action in Humans: A Critical Appraisal. Diabetologia, 47, 943-956. https://doi.org/10.1007/s00125-004-1381-z

6. Guigliano, D., Passariello, N., Sgambato, S., Torella, R. and D’Onofrio, F. (1982) Calcitonin Modulation of Insulin and Glucagons secretion in Man. American Journal of Physiology, 242, E206-E213.

7. Iorns, A., Tiedge, M. and lenzen, S. (2002) Thyroxine Induces Pancreatic Beta-Cells Apoptosis in Rats. Diabetologia, 45, 851-855. https://doi.org/10.1007/s00125-002-0842-5

8. Sandomirskaya, L.D., Lotova, V.I., Kokoreva, G.A. and Kurbatova, L.A. (2000) Reaction of Thyroid Gland on Calcitonin Injection. Proceedings V International Association of Morphologists, Morphology, Moscow, 117, 106.

9. Soonthornpun, S., Setasuban, W., Thamprasit, A., Chayanunnukul, W., Rattarasam, C. and Geater, A. (2003) Novel Insulin Sensitivity Index Derived from Oral Glucose Tolerance Test. The Journal of Clinical Endocrinology \& Metabolism, 88, 1019-1023. https://doi.org/10.1210/jc.2002-021127

10. Cheatham, B. (2000) GLUT and Company: SNAREing Roles in Insulin-Regulated Glucose Uptake. Trends in Endocrinology and Metabolism, 11, 356-361. https://doi.org/10.1016/S1043-2760(00)00308-8

11. Butakova (Moisa), S.S. and Nozdrachev, A.D. (2009) Effect of Calcium-Regulating Hormones and Calcium Channel Modulators on Glucose Consumption by Muscle and Adipose Tissues in Vivo and in Vitro. Bulletin of Experimental Biology and Medicine, 148, 171-174. https://doi.org/10.1007/s10517-009-0677-x

12. Butakova (Moisa), S.S. and Nozdrachev, A.D. (2011) Mechanisms of Hyperglycemic Effect of Calcitonin. Bulletin of Experimental Biology and Medicine, 150, 320-323. https://doi.org/10.1007/s10517-011-1132-3

13. Garel, J.-M., Barlet, J.P. and Kervran, A. (1975) Metabolic Effects of Calcitonin in the Newborn. American Journal of Physiology, 229, 669-675.

14. Moore, M.C., Lin, D.W. and Colburn, C.A. (1999) Insulin- and Glucagons-Independent Effects of Calcitonin Gene-Related Peptide in the Conscious Dog. Metabolism: Clinical and Experimental, 48, 603-610. https://doi.org/10.1016/S0026-0495(99)90058-6

15. Cahova, M., Vavrinkova, H. and Kazdova, L. (2007) Glucose-Fatty Acid Interaction in Skeletal Muscle and Adipose Tissue in Insulin Resistance. Physiological Research, 56, 135-140.

16. Kelley, D.E., Goodpaster, B.H. and Storlien, L. (2002) Muscle Triglyceride and Insulin Resistance. Annual Review of Nutrition, 22, 325-346. https://doi.org/10.1146/annurev.nutr.22.010402.102912

17. Vel'kov, V.V. (2008) Free Fatty Acids-A New Marker of Insulin Resistance and Ischemia. Far-East Medical Journal, 4, 120-122.

18. Zhao, H.-L., Liu, L.-Z., Sui, Y., Ho, S.K.S., Tam, S.-K., Lai, F.M.M., Chan, J.C.N. and Tong, P.C.Y. (2010) Fatty Acids Inhibit Insulin-Mediated Glucose Transport Associated with Actin Remodeling in Rat L6 Muscle Cells. Acta Diabetologica, 47, 331-339. https://doi.org/10.1007/s00592-010-0225-1

19. Yamaguchi, M., Momose, K. and Takahashi, K. (1985) Stimulatory Effect of Calcitonin on Fatty Acid Synthesis in the Liver of Fed Rats. Hormone and Metabolic Research, 17, 346-350. https://doi.org/10.1055/s-2007-1013539

20. Passariello, N., Guigliano, D., Sgambato, S., Torella, R. and D’Onofrio, F. (1981) Calcitonin, A Diabetogenic Hormone? The Journal of Clinical Endocrinology and Metabolism, 53, 318-323.

https://doi.org/10.1210/jcem-53-2-318 
21. Williams, P.F., Watson, S.K. and Turtle, J.R. (1981) Lanthide Interactions with the Calcium Binding Site of Insulin Receptor. The Endocrine Society of Australia, 24, 50.

22. Telkova, I.L. (2005) Molecular-Cell Effects of Insulin and Possible Mechanisms of Insulin Resistance Development in Patients with IDC. Advances in Physiology Education, 36, 55-65.

23. Reaven, G.M. (2004) The Metabolic Syndrome or the Insulin Resistance Syndrome? Different Names, Different Concepts, and Different Goals. Endocrinology and Metabolism Clinics of North America, 33, 283-303. https://doi.org/10.1016/j.ecl.2004.03.002

24. Roitberg, G.E. (2007) Metabolic Syndrome. In: Roitberg, G.E., Ed., Metabolic Syndrome, Moscow, 223.

25. Kononenko, I.V., Prokofev, S.A. and Smirnova, O.M. (2004) Functional State of B-Cell, Immunological and Clinic-Biochemical Characteristics in the Patients with Low-Progressive Autoimmune Diabetes Adult. Pediatric Endocrinology Reviews, 50, 18-22.

26. Isomaa, B., Henricsson, M., Almgren, P., Tuomi, T., Taskinen, M.-R. and Groop, L. (2001) The Metabolic Syndrome Influences the Risk of Chronic Complications in Patients with Type II Diabetes. Diabetologia, 44, 1148-1154. https://doi.org/10.1007/s001250100615

27. Temelkova, S. (2002) Osteoporosis, Induced by Glucocorticoids-a New Problem of the Present Time. Endocrinologia, 7, 24-54.

28. Mc Dermott, M.T., Kidd, G.S., Blue, P., Ghaed, V. and Hofeldt, F.D. (1983) Reduced Bone Content in Totally Thyroidectomized Patients: Possible Effect of Calcitonin Deficiency. Journal of Clinical Endocrinology and Metabolism, 56, 936-939. https://doi.org/10.1210/jcem-56-5-936

29. Gattereau, A., Bielmann, P. and Durivage, J. (1977) Hyperglycaemic Effect of Synthetic Salmon Calcitonin. Lancet, 2, 1076-1077. https://doi.org/10.1016/S0140-6736(77)91908-0

30. Freed, W.J., Perlow, M.J. and Wyatt, R.J. (1979) Calcitonin: Inhibitory Effect on Eating in Rats. Science, 206, 850-852. https://doi.org/10.1126/science.493987

31. Ziegler, R. (1983) Calcitonin and the Endocrine Pancreas. Triangle, 22, 135-145.

32. Moisa, S.S. and Nozdrachev, A.D. (2013) One-Time Injection of Calcitonin Induces Glucose Intolerance in Children with the $1^{\text {st }}$ Degree Obesity. Health, 5, 9-13. https://doi.org/10.4236/health.2013.56A1002

33. Tomic, M., Poljicanin, T., Pavlic-Renar, I. and Meelko, Z. (2003) Obesity-A Risk Factor for Microvascular and Neuropathic Complications in Diabetes? Diabetologia Croatica, 32, 73-78.

34. Dianov, O.A., Gnusaev, S.F., Yakovlev, B.N. and Gorshkova, M.I. (2008) Neuro-Circular Non-Stability and Metabolic Disorders in Children with Obesity and Its Correction. Vestnik of Pediatric Pharmacology and Nutrimnology, 5, 34-38.

35. Zhu, J.-F., Liang, L., Wang, C.-L. and Zhou, C.-C. (2006) Dissemination of Complications in Teenagers with Moderate and Hard Obesity. Journal of Applied Clinical Pediatrics, 21, 1320-1321.

36. Zhang, X., Yu, C. and Li, S. (2003) Insulin and C-Peptide Level in Blood Serum Children with Simple Obesity. Journal of Applied Clinical Pediatrics, 18, 28-29.

37. Liu, R.H., Mizuta, M., Kurose, T. and Matsukura, S. (2002) Early Events Involved in the Development of Insulin Resistance in Zuker Fatty Rats. International Journal of Obesity, 26, 318-326.

https://doi.org/10.1038/sj.ijo.0801924

38. Kravets, E.B. (1983) Insulin System State under Obesity in Children. In: Kravets, E.B., Ed., Biochemical Identification of Pathological Processes in Clinic and Experiment, Medicine, Moscow, 21-24.

39. Butakova, S.S. and Nozdrachev, A.D. (2010) Effect of Calcitonin on the Type of Alimentary Hyperglycemia in Rats of Different Age and Sex. Advances in Gerontology, 23, 213-220. 
40. Fink, R.I., Kolterman, O.G., Kao, M. and Olefsky, J.M. (1984) The Role of the Glucose Transport System in the Postreceptor Defect in Insulin Action Associated with Human Aging. The Journal of Clinical Endocrinology and Metabolism, 58, 721-725. https://doi.org/10.1210/jcem-58-4-721

41. Asghar, Z., Yau, D., Chan, F., Le Roith, D., Chan, C.B. and Wheeler, M.B. (2006) Insulin Resistance Causes Increased Beta-Cells Mass but Defective Glucose-Stimulated Insulin Secretion in a Murine Model of Type 2 Diabetes. Diabetologia, 49, 90-99. https://doi.org/10.1007/s00125-005-0045-y

42. Rustenbeck, I. (2002) Desentization of Insulin Secretion. Biochemical Pharmacology, 63, 1921-1935. https://doi.org/10.1016/S0006-2952(02)00996-6

43. Baranov, V.G. and Yaroshevskii, Yu.A. (1980) About Relative Insulin Deficiency as a Primary Factor of Spontaneous Diabetes Mellitus Pathogenesis. Pediatric Endocrinology Reviews, 26, 3-7.

44. Lasyi, V.P. (2004) Clinic-Instrumental and Laboratory Criterions of the Assessment of the Peculiarities of Tissue Metabolism under Acid-Dependent Diseases of Digestion Organs. Ph.D. Dissertation, Russian Military-Medical Academy, St-Petersburg.

45. Mosin, V.I., Yagoda, A.V. and Grossman, B.E. (1980) Parathormone, Calcitonin and Cyclic Adenosine-MonoPhosphate Content in Blood under Diabetes Mellitus. Therapeutic Archive, 52, 80-83.

46. Zhukovskii, M.A., Yurkov, A.I. and Babaev, K. (1974) The Peculiarities of the Spectrum of Laktat- Dehydrogenase Isoferments in Children Blood Serum, Suffered from Diabetes Mellitus, Depending on Compensation State. Questions of Maternity and Childhood Guard, 19, 90-96.

47. Scott, F.W., Trick, K.D., Lee, L.P.K., Hynie, I., Heick, H.M.C. and Nera, E.A. (1984) Serum Enzymes in the BB Rat before and after Onset of the Overt Diabetic Syndrome. Clinical Biochemistry, 17, 270-275.

https://doi.org/10.1016/S0009-9120(84)90200-5

48. Fraze, E., Donner, C.C., Swislocki, A.L.M., Chion, Y.-A.M., Chtm, Y.-D.I. and Reaven, G.M. (1985) Ambient Plasma Free Fatty Acid Concentrations in Noninsulin-Dependent Diabetes Mellitus Evidence for Insulin Resistance. The Journal of Clinical Endocrinology and Metabolism, 61, 897-811. https://doi.org/10.1210/jcem-61-5-807

49. Kulikova, L.I., Tsvetkov V.S., Bondarenko, M.F. and Gordienko, S.P. (1985) Anti-Bodies to Calcitonin under Experimental Diabetes Mellitus. Bulletin of Experimental Biology and Medicine, 99, 422-424. https://doi.org/10.1007/BF00842732

50. Kosovskii, M.I., Khysainova, F.A. and Gulyamov, T.D. (1982) The Decreasing of Tissue Insulin Sensitivity in Rats after Hydrocortisone or Indometacine Injection, Correlation with Prostaglandin Effect. Pediatric Endocrinology Reviews, 28, 57-60.

51. Ertel, E.A., Campbell, K.P., Harpold, M.M., Hofmann, F., Mori, Y., Perez-Reyes, E., Schwartz, A., Snutch, T.P., Tanabe, T., Birnbaumer, L., Tsien, R.W. and Catterall, W.A. (2000) Nomenclature of Voltage-Gated Calcium Channels. Neuron, 25, 533-535. https://doi.org/10.1016/S0896-6273(00)81057-0

52. William O, W., Michael B, Z. and Naima, M.-M. (2003) Modulation of the Sulfonylurea Receptor and Calcium in Adipocyties for Treatment of Obesity/Diabetes. US Patent No. 6100047.

53. Byyny, R.L., Loverde, M., Llotd, S., Mitchell, W. and Draznin, B. (1992) Cytosolic Calcium and Insulin Resistance in Elderly Patients with Essential Hypertension. American Journal of Hypertension, 5, 459-464. https://doi.org/10.1093/ajh/5.7.459

54. Hagstrom, E., Hellman, P., Lundgren, E., Lind, L. and Arnlov, J. (2007) Serum Calcium Is Independently Associated with Insulin Sensitivity Measured with Euglycaemic-Hyperinsulinaemic Clamp in a Community Based Cohort. Diabetologia, 50, 317-324. https://doi.org/10.1007/s00125-006-0532-9

55. Kiseleva, T.P. (2008) Disturbances of Phosphorus-Calcium Metabolism under Diabetes Mellitus 1 Type. Pro- 
ceedings 15th Russian National Congress Man and Drugs, Moscow, 18 April, 432-433.

56. Levy, J. (1999) Abnormal Cell Calcium Homeostasis in Type 2 Diabetes Mellitus: A New Look on Old Disease. Endocrine, 10, 1-6. https://doi.org/10.1385/ENDO:10:1:1

57. Advani, A., Marshall, S.M. and Thomas, T.H. (2004) Impaired Neutrophil Store-Mediated Calcium Entry in Type 2 Diabetes. European Journal of Clinical Investigation, 34, 43-49. https://doi.org/10.1111/j.1365-2362.2004.01291.x

58. Tytskaya Y.A. (2004) Bone Tissue Metabolism under Diabetes Mellitus in Children. Ph.D. Dissertation, Izhevsk State Medical Academy, Izhevsk.

59. Falameeva, O.V. (2008) Scientific Bases of Preventive Measures of Osteoporosis in Childish, Adolescent and Youthful Age on Population Level. Ph.D. Dissertation, Novosibirsk Medical Institute, Novosibirsk.

60. op den Buijs, J., Miklos, Z., van Riel, N.A., Prestia, C.M., Szenczi, O., Toth, A., Van der Vusse, G.J., Szabo, C., Ligeti, L. and Ivanics, T. (2005) Beta-Adrenergic Activation Reveals Impaired Cardiac Calcium Handling at Early Stage of Diabetes. Life Science, 76, 1083-1098. https://doi.org/10.1016/j.lfs.2004.08.018

61. Ward, D.T., Yau, S.K., Mee, A.P., Mawer, E.B., Miller, C.A., Garland, H.O. and Riccardi, D. (2000) Functional and Molecular Characterization of Diabetic Hypercalciuria. Journal of Physiology and Proceeding, 527, 13.

62. Zhou, Z.-H., Zhuang, L.-Y. and Song, Y.-J. (2002) Effect of Nifedipin Therapy on Insulin Resistance in Elderly Patients with Hypertension. Chinese Journal of New Drugs and Clinical Remedies, 21, 491-492.

63. Wen, Z.-Y., Wu, Y., Li, Y., Chen, X.-L., Wang, T., Ouyang, J.-P. and Li, G.-S. (2005) Changing of GLUT-4 under Diabetes Mellitus 2 Type and Its Influence on Glucose and Fatty Acids in Myocardium. Chinese Medical Journal, 85, 1460-1463.

64. Mychka, V.B., Gornostaeva, V.V., Bogieva, R.M. and Chazova, I.E. (2001) Arterial Hypertension in Patients with Diabetes Mellitus and Metabolic Syndrome. Consilium Medicum. Arterial Hypertension, 1, 25-31.

65. Fel'dsherova N.A. and Semernin, E.N. (2002) Amlodipin: Review of Clinic Research. Qualitative Clinical Practice, 2, 27-33.

66. Chazova I.E. and Mychka, V.B. (2004) Calcium Channel Blockers. Metabolic Syndrome. Consilium Medicum, $4,168$.

67. Chazova I.E. and Mychka, V.B. (2008) Metabolic Syndrome. Media Medica, Moscow.

68. Butakova, S.S. and Nozdrachev, A.D. (2012) Calcium Channel Blockers Inhibit the Hyperglycemic Effect of Calcitonin. Bulletin of Experimental Biology and Medicine, 152, 553-559. https://doi.org/10.1007/s10517-012-1573-3

69. Mc Carty, M.F. (2006) PKC-Mediated Modulation of L-Type Calcium Channels May Contribute to Fat-Induced Insulin Resistance. Medical Hypotheses, 66, 824-831. https://doi.org/10.1016/j.mehy.2004.08.034

70. Hemandez, R.H., Armas-Hemandez, M.Y. and Velasco, M. (2003) Calcium Antagonists and Atherosclerosis Protection in Hypertension. American Journal of Therapeutics, 10, 409-414. https://doi.org/10.1097/00045391-200311000-00006

71. Shilova, E.V. and Martsevich S.Y. (2008) Dihydropyridine Calcium Antagonists: Role in Modern Therapy of Cardiovascular Diseases. Rational Pharmacotherapy in Cardiology, 2, 53-57. https://doi.org/10.20996/1819-6446-2008-4-2-53-57

72. Zanos, S., Mitsopoulos, E. and Sakellariou, G. (2005) Parathyroid Hormone Levels, Calcium-Channel Blockers, and the Dyslipidemia of Non-Diabetic Hemodialysis Patients. Renal Failure, 2, 163-169.

https://doi.org/10.1081/JDI-48229 
73. Vislobokov, A.I., Ignatov, Y.D., Galenko-Yaroshevskii, P.A. and Shabanov P.D. (2010) Membrane-Tropos Effect of Pharmacological Drugs. Enlightment-South, St.-Petersburg-Krasnodar.

74. Davalli, A.M., Biancardi, E., Pollo, A., Socci, C., Pontiroli, A.F., Pozza, G., Climinti, F., Sher, E. and Carbone, E. (1996) Dihydropyridine-Sensitive and -Insensitive Voltage-Operated Calcium Channels Participate in the Control of Glucose-Induced Insulin Release from Human Pancreatic B-cells. Journal of Endocrinology, 150, 195-203. https://doi.org/10.1677/joe.0.1500195

75. Roe, M.W., Worley, J.F., Tokuyama, Y., Philipson, K.H., Sturis, J., Tang, J., Dukes, J.D., Bell, G.I. and Polonsky, K.S. (1997) NIDDM Is Associated with Loss of Pancreatic $\mathcal{B}$-Cell L-Type $\mathrm{Ca}^{2+}$-Channel Activity. American Journal of Physiology, 270, 133-140.

\section{Submit or recommend next manuscript to SCIRP and we will provide best service for you:}

Accepting pre-submission inquiries through Email, Facebook, LinkedIn, Twitter, etc.

A wide selection of journals (inclusive of 9 subjects, more than 200 journals)

Providing 24-hour high-quality service

User-friendly online submission system

Fair and swift peer-review system

Efficient typesetting and proofreading procedure

Display of the result of downloads and visits, as well as the number of cited articles

Maximum dissemination of your research work

Submit your manuscript at: http://papersubmission.scirp.org/

Or contact jbise@scirp.org 